\section{Amino-acid Composition of Aplysia Myoglobin}

Several years ago we isolated from the buccal muscles of the common Mediterranean molluse Aplysia a myoglobin which showed a number of interesting features when compared with mammalian myoglobins s,2 $^{1,}$

Preliminary amino-acid analysis indicated that the composition of Aplysia myoglobin is quite different from that of mammalian myoglobins, and in particular that there appears to be only one histidyl residue per molecule. This constitutes a particularly interesting feature in view of the role which is attributed to the iron-binding proximal and distal imidazoles in mammalian myoglobin and haemoglobin. In addition, Aplysia myoglobin was found to undergo a rapidly reversible thermal denaturation, which has been studied in some detail ${ }^{3}$. analyses were carried out using the method of Spackman et al. ${ }^{4}$. The tryptophan content was determined by the $N$-bromosuccinimide method of $\mathrm{RaO}$ and Cama ${ }^{5}$. After tryptic digestion of the globin peptide patterns were obtained by the method of Ingram, as modified by Baglioni ${ }^{6}$. The sugar content of Aplysia myoglobin was analysed quantitatively by the method of Dubois? for the non-nitrogenous sugars, and by the method of Rondle and Morgan ${ }^{8}$ for the 2-amino sugars.

As in previous studies, the purified Aplysia myoglobin was found to be homogeneous by starch gel electrophoresis and by ultracentrifugation. Analysis of the sugars in the purified protein has shown that Aplysia myoglobin does not contain non-nitrogenous or 2-amino sugars (sugar content less than 1 per cent).

The amino-acid composition of Aplysia myoglobin is reported in Table 1. The new data, which are the average

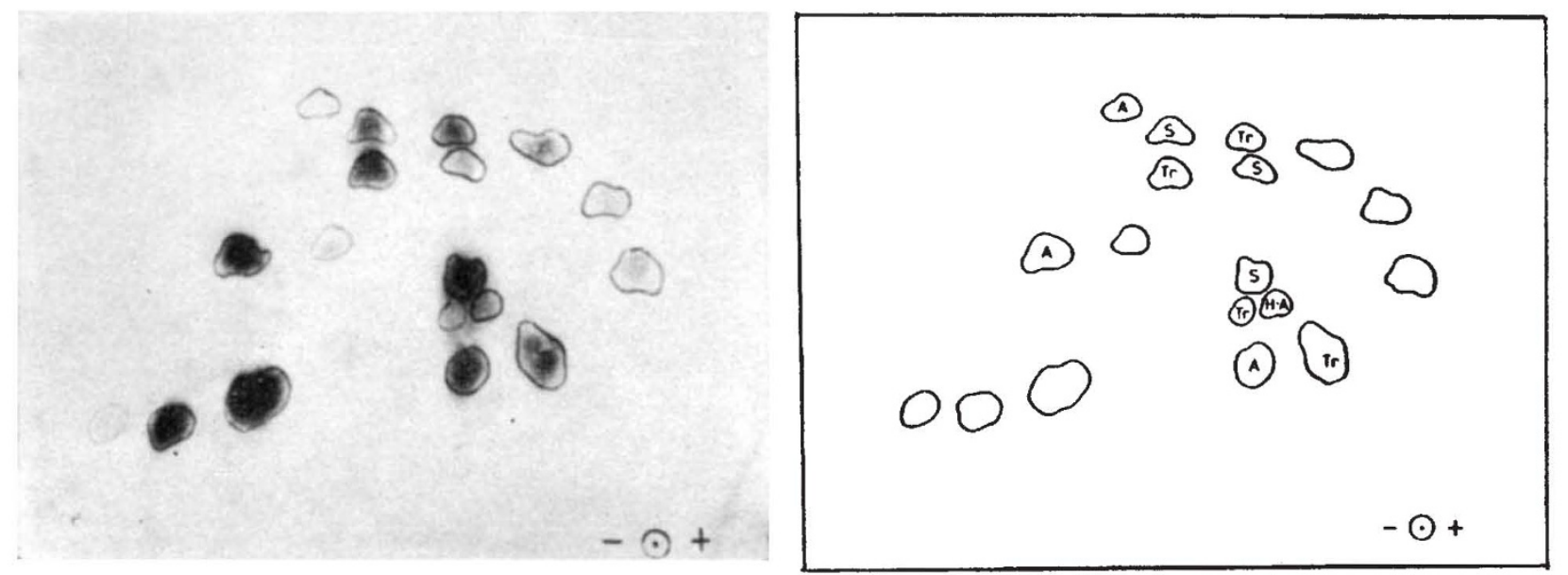

Fig. 1. Fingerprint and fingerprint tracing of tryptic digest of Aplysia myoglobin. Code for specifle staining test: A=arginine; $\mathrm{H}=\mathrm{histidine}$; $\mathrm{S}=$ sulphur; $\mathrm{Tr}=$ tryptophan.

These peculiar properties, together with the detailed knowledge now available about the structure and physicochemical and functional properties of mammalian myoglobins, stimulated a more complete chemical analysis of Aplysia myoglobin. We report here the amino-acid composition and peptide pattern in Aplysia myoglobin; the new results complement the old observations and serve as a basis for sequence studies, which are in progress.

Aplysiae (Limacina) were obtained from the Zoological Station, Naples. The radulas, isolated from the animals just after capture, were frozen at $-20^{\circ} \mathrm{C}$ and stored at this temperature until the extraction of myoglobin. Myoglobin was purified as described earlier ${ }^{1}$. Amino-acid

Table 1. AMrNo-ACID COMposition of Aplysia MYogLoBin

\begin{tabular}{|c|c|c|c|c|c|}
\hline & $\begin{array}{c}\text { Amino-acids } \\
(\mathrm{g} / 1.00 \mathrm{~g} \\
\text { of protein) }\end{array}$ & $\begin{array}{l}\text { Residues } \\
\text { (g/100 g } \\
\text { of protein) }\end{array}$ & $\begin{array}{l}\text { Nitrogen } \\
(\mathrm{g} / \mathbf{1 0 0} \mathrm{g} \\
\text { of total } \mathrm{N})\end{array}$ & $\begin{array}{l}\text { No. of resi- } \\
\text { dues per } \\
\text { molecule } \\
\text { (molecular } \\
\text { weight, 18,000) }\end{array}$ & $\begin{array}{c}\text { No. of resi- } \\
\text { dues per } \\
\text { molecule } \\
\text { (nearest } \\
\text { integer) }\end{array}$ \\
\hline Lys & $10 \cdot 28$ & $9 \cdot 02$ & $12 \cdot 03$ & 13.00 & 13 \\
\hline His & 0.83 & 0.73 & $1 \cdot 34$ & 0.95 & 1 \\
\hline $\mathrm{N}-\mathrm{NH}_{2}$ & 1.08 & & $5 \cdot 74$ & $(12 \cdot 51)$ & (13) \\
\hline Arg & $3 \cdot 81$ & $3 \cdot 41$ & $7 \cdot 51$ & 4.06 & 4 \\
\hline Asp & $13 \cdot 78$ & $11 \cdot 92$ & 8.85 & $19 \cdot 11$ & 19 \\
\hline Thr & 1.34 & $1 \cdot 13$ & 0.98 & 1.96 & 2 \\
\hline Ser & $8 \cdot 47$ & 7.02 & 6.90 & $13 \cdot 58$ & 14 \\
\hline Glu & 6.44 & 5.65 & $3 \cdot 72$ & 8.03 & 8 \\
\hline Pro & $4 \cdot 18$ & $3 \cdot 53$ & $3 \cdot 11$ & $6 \cdot 30$ & 6 \\
\hline Gly & 4.90 & $3 \cdot 73$ & $5 \cdot 56$ & $12 \cdot 02$ & 12 \\
\hline Ala & $15 \cdot 72$ & $12 \cdot 54$ & $15 \cdot 07$ & $32 \cdot 54$ & 33 \\
\hline Cys $/ 2$ & & & & & \\
\hline Val & $7 \cdot 25$ & $6 \cdot 14$ & $5 \cdot 31$ & $10 \cdot 99$ & 11 \\
\hline Met & $2 \cdot 50$ & $2 \cdot 20$ & $1 \cdot 40$ & 3.09 & 3 \\
\hline I Leu & $3 \cdot 11$ & $2 \cdot 48$ & $2 \cdot 01$ & 4.21 & 4 \\
\hline Leu & $7 \cdot 70$ & 6.65 & 5.01 & $10 \cdot 83$ & 11 \\
\hline Tyr & $=$ & & & & \\
\hline Phe & $15 \cdot 27$ & $13 \cdot 61$ & $7 \cdot 87$ & $17 \cdot 04$ & 17 \\
\hline Try & 3.88 & 3.54 & 2.99 & 3.94 & 4 \\
\hline Sub-total & l 110.54 & $93 \cdot 50$ & $9 \overline{5} \cdot 40$ & & \\
\hline Heme & 2.93 & 2.93 & 1.65 & $1 \cdot 00$ & (1) \\
\hline Total & $113 \cdot 47$ & $96 \cdot 43$ & $97 \cdot 05$ & & 162 \\
\hline
\end{tabular}

of six separate analyses, are in general agreement with the preliminary ones ${ }^{2}$ and confirm the large differences between Aplysia and mammalian myoglobins in respect of amino-acid composition. Particularly noteworthy in Aplysia myoglobin is the absence of tyrosyl residues and the presence of only one histidine per molecule.

Peptide maps obtained from the tryptic digest are shown in Fig. 1. The number of peptides agrees with the arginine and lysine content of the protein. Only one peptide gives a specific reaction for histidine and this is consistent with the finding that there is only one histidine residue per molecule. Attempts to analyse the amino terminal groups by the D.F.B. method gave no answer. This suggests that the $N$-terminal group is acetylated in Aplysia myoglobin. Carboxypeptidases $A$ and $B$ failed to give any digestion products from either the whole protein or the apoprotein.

Istituto Superiore di Sanità, Rome.

LEONARDO TENTORI Gerolamo Vivalid SALVATORE CARTA

Institutes of Biological Chemistry of Rome

Eraldo Antonini MaURIZIO BRUNORI

and Camerino,

CNR Centre for Molecular Biology,

Rome.

Rossi Fanelli, A., and Antonini, E., Biochimia (URSS), 22, 336 (1957).

Rossi Fanelli, A., Antonini, E., and Povoledo, D., in Symp. on Protein Structure, 144 (edit. by Neuberger, A.) (Methuen, London, 1957).

${ }^{3}$ Brunori, M., Antonini, E., Fasella, P., Wyman, J., and Rossi Fanelli, A., J. Mol. Biol. (in the press).

4 Spackman, D. H., Stein, W. H., and Moore, S., Anal. Chem.. 30, 1190 (1958)

${ }^{5}$ Rao, J. S., and Cama, H. R., Biochim. Biophys. Acta, 71, 139 (1963)

${ }^{6}$ Baglioni, C., Biochim. Biophys. Acta, 48, 392 (1961).

'Dubois, M., Anal. Chem., 28, 350 (1956).

${ }^{8}$ Rondle, C. M. J., and Morgan, W. T. J., Biochem. J., 61, 586 (1955). 